University of Nebraska - Lincoln

DigitalCommons@University of Nebraska - Lincoln

Mammalogy Papers: University of Nebraska

State Museum

Museum, University of Nebraska State

2-14-1981

\title{
A New Species of Rhynchomys (Muridae) from the Philippines
}

Guy G. Musser

American Museum of Natural History

Patricia W. Freeman

University of Nebraska-Lincoln, pfreeman1@unl.edu

Follow this and additional works at: https://digitalcommons.unl.edu/museummammalogy

Part of the Zoology Commons

Musser, Guy G. and Freeman, Patricia W., "A New Species of Rhynchomys (Muridae) from the Philippines" (1981). Mammalogy Papers: University of Nebraska State Museum. 16.

https://digitalcommons.unl.edu/museummammalogy/16

This Article is brought to you for free and open access by the Museum, University of Nebraska State at DigitalCommons@University of Nebraska - Lincoln. It has been accepted for inclusion in Mammalogy Papers: University of Nebraska State Museum by an authorized administrator of DigitalCommons@University of Nebraska Lincoln. 


\section{GENERAL NOTES}

\section{A NEW SPECIES OF RHYNCHOMYS (MURIDAE) FROM THE PHILIPPINES}

“... Mr. Whitehead has made a most wonderful and unexpected discovery, that of a new and peculiar Mammal-fauna inhabiting the Luzon highlands, and, so far as is yet known, mostly isolated on a small plateau on the top of Monte Data, in the centre of Northern Luzon, at an altitude of from 7000 to 8000 feet." With this dramatic announcement, Oldfield Thomas (1898:377) introduced to naturalists the spectacular rats found by Whitehead: Crateromys schadenbergi, Carpomys melanurus, C. phaeurus, Batomys granti, Chrotomys whiteheadi, Celaenomys silaceus, and Rhynchomys soricoides. One of the most interesting of these to Thomas was $\boldsymbol{R}$. soricoides, which he had previously named and briefly described in 1895 . This shrew-rat is medium-sized with a very long muzzle, small eyes, short dense fur, dark brown upperparts, gray underparts, a short brown tail, and brown feet. Its very long and slender rostrum, small zygomatic plates, small white incisors, and tiny basined teeth indicated adaptations for special foods, possibly soft-bodied invertebrates. Nothing quite like Rhynchomys had been discovered before, either in the Philippines or elsewhere.

Thomas based his description of $R$. soricoides on five individuals collected by Whitehead, all from Mount Data. Two others were obtained from Mount Data during 1946 and subsequently reported by Sanborn (1952). Rhynchomys was represented by these specimens until 1961, when an example was caught on Mount Isarog in the southeastern part of Luzon. That specimen, which forms the nucleus of our report, is significant because it indicates that Rhynchomys occurs on at least one other highland in Luzon, and because some of its morphological features fall outside the range of variation of the series taken on Mount Data. The differences in external and cranial characters between the two samples suggest to us that the specimen from Mount Isarog was drawn from a population that is reproductively isolated from that on Mount Data. We hypothesize that the specimen represents a new species, which we name and describe below.

\section{Rhynchomys isarogensis, new species}

Holotype.-An adult male (scrotal testes; basisphenoid suture fused and indistinct) collected on 14 April 1961 by D. S. Rabor (original field number, 1434), and deposited in the Field Museum of Natural History, Chicago (FMNH 95123). The skin is in good condition except for small bare patches on the venter. The cranium is slightly damaged: most of the left and part of the right jugals, and both right upper molars are missing (Fig. 1). The angular process of the left dentary and the $\mathbf{M}_{2}$ of each dentary are missing.

Measurements.-See Table 1. External measurements are those of collectors (except for length of hindfoot, which we measured) and were taken from skin labels. Cranial measurements were taken with a craniometer attached to a Wild M5 microscope or dial calipers graduated in tenths of $\mathrm{mm}$. Limits of the cranial measurements are explained by Musser (1970) except for: length of rostrum, from tip of nasals perpendicular to a line connecting anteriolateral margins of dorsal maxillary roots of zygomatic arches; length of palatal bridge, from posterior edges of incisive foramina to anterior border of mesopterygoid fossa; length of palate behind toothrow, from posterior alveolus of toothrow to end of palate; length of bulla, excluding bony eustachian tube; incisive foramina to $\boldsymbol{M}^{1}$, from back edge of incisive foramina to anterior margin of toothrow; length of dentary and $I_{1}$, from back of dentary to tip of incisor; and length of dentary minus $I_{1}$, total length of dentary. Morphological features of FMNH 62289 and 62290 (Table 1) match the five specimens collected by Whitehead, which were studied by Musser at the British Museum.

Type locality.-Mount Isarog, at $5,500 \mathrm{ft}$, southeastern peninsula of Luzon Island, Camarines Sur Province, the Philippines (Fig. 2).

Distribution.-Known only from Mount Isarog. 

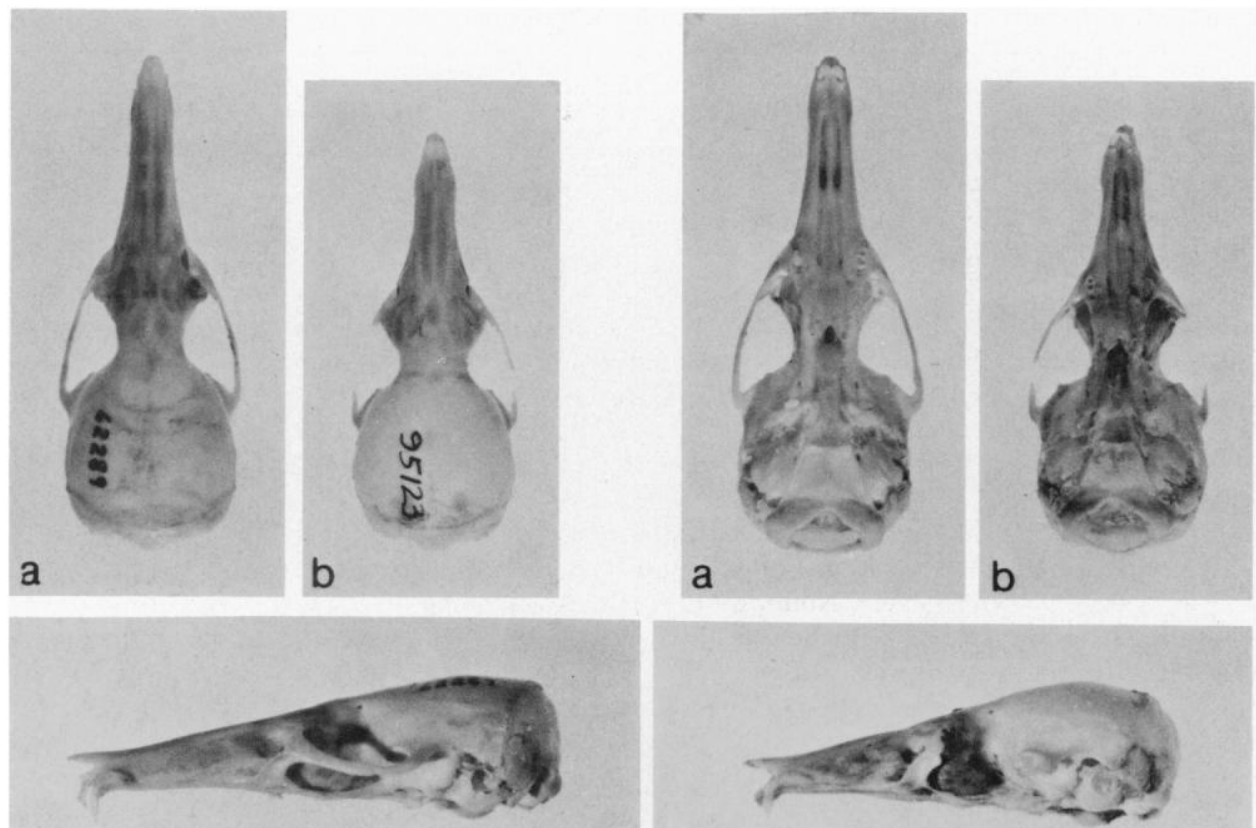

a

\section{b}

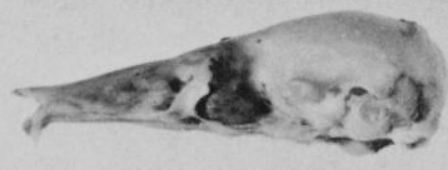

Fig. 1.-Dorsal, ventral, and lateral views of Rhynchomys crania: a, R. soricoides (FMNH 62289); b, R. isarogensis (FMNH 95123). Both crania are from adults of comparable age. Approximately natural size.

\section{Referred material.-The holotype.}

Etymology.-Named for the mountain on which the holotype was collected.

Diagnosis.-A species of Rhynchomys resembling R. soricoides but distinguished from it by the following features: body smaller (Table 1); tail relatively shorter, dark brown above and unpigmented below except for a narrow midventral strip (instead of monocolored dark brown); feet white (instead of dark brown); cranium and mandibles smaller (Table 1); braincase round and more inflated, larger relative to rest of cranium; palate anterior to the upper molars more arched transversely; mandibular condyles longer and thicker transversely.

Description and comparison.-A stout body, tail much shorter than the head and body, small eyes, and very long muzzle characterize $R$. isarogensis; most of its body proportions are similar to those of $R$. soricoides (see the live-pose depicted in Thomas, 1898: pl. 31), except length of tail, which is shorter relative to length of head and body (length of tail/length of head and body are 76\%, 68\%, and 56\% in FMNH 62290, 62289 , and 95123 , respectively). Upperparts of the head and body of $R$. isarogensis are covered by thick, short, and soft brown fur, velvety to the touch. The coloration is like that in $R$. soricoides, but the pelage is not as thick and long, and the ears are paler. The underparts appear whitish gray (hairs are white for most of their lengths with short gray bases), instead of gray or dark gray as in $R$. soricoides. Dorsal surfaces of the feet are white, the palmar and plantar surfaces (including the pads) are unpigmented, and the claws are gracile. $R$. soricoides has dark brown feet, disproportionally smaller pads, and more robust claws. The tail of $R$. isarogensis is short and scantily haired. Its dorsal surface is brown, its ventral surface unpigmented except for a narrow midventral brown strip extending from base to tip. The tail hairs are short, three 
TABLE 1.-Measurements (in $\mathrm{mm}$ ) of Rhynchomys soricoides and $\mathrm{R}$. isarogensis from Luzon.

\begin{tabular}{|c|c|c|c|}
\hline \multirow[b]{2}{*}{ Measurements } & \multicolumn{2}{|c|}{ R. soricoides } & \multirow{2}{*}{$\frac{\text { R. isarogensis }}{\underset{\text { FMNH }}{\text { adult }} \text { 95123 }}$} \\
\hline & $\begin{array}{c}\text { FMNH } 62290 \\
\text { young adult }\end{array}$ & $\underset{\text { adult }}{\text { FMNH } 62289}$ & \\
\hline Length of head and body & 188 & 195 & 187 \\
\hline Length of tail & 143 & 132 & 105 \\
\hline Length of hindfoot & 42 & 41 & 37 \\
\hline Length of ear (from notch) & 21 & 20 & 18 \\
\hline Greatest length of skull & 46.7 & 49.3 & 43.1 \\
\hline Length of nasals & 18.8 & 20.2 & 16.7 \\
\hline Length of rostrum & 20.8 & 22.2 & 17.5 \\
\hline Breadth of rostrum & 6.8 & 7.3 & 7.3 \\
\hline Zygomatic breadth & 16.8 & 18.2 & 16.8 \\
\hline Interorbital breadth & 6.7 & 6.3 & 6.7 \\
\hline Breadth of braincase & 16.4 & 16.5 & 16.3 \\
\hline Height of braincase & 12.5 & 12.1 & 12.2 \\
\hline Breadth across zygomatic plate & 1.6 & 2.2 & 2.0 \\
\hline Length of diastema & 15.4 & 16.7 & 13.2 \\
\hline Palatilar length & 23.1 & 23.4 & 19.7 \\
\hline Palatal length & 24.4 & 25.4 & 20.9 \\
\hline Postpalatal length & 15.3 & 17.0 & 15.1 \\
\hline Length of incisive foramina & 7.0 & 7.5 & 5.9 \\
\hline Breadth across incisive foramina & 2.0 & 2.0 & 2.0 \\
\hline Length of palatal bridge & 13.6 & 14.3 & 11.8 \\
\hline Length of palate behind toothrow & 5.2 & 4.8 & 4.3 \\
\hline Breadth of palate at $\mathrm{M}^{1}$ & 4.9 & 5.3 & 5.0 \\
\hline Breadth of mesopterygoid fossa & 2.1 & 2.1 & 2.0 \\
\hline Breadth across incisor tips & 1.5 & 1.5 & 1.3 \\
\hline Length of bone in front of incisors & 1.1 & 1.0 & 0.9 \\
\hline Length of bulla & 5.4 & 5.0 & 4.6 \\
\hline Height of bulla & 4.9 & 4.5 & 3.8 \\
\hline Alveolar length of $\mathrm{M}^{1-2}$ & 2.3 & 2.2 & 2.1 \\
\hline Length of $\mathbf{M}^{1}$ & & 1.4 & 1.4 \\
\hline Breadth of $\mathbf{M}^{1}$ & & 0.8 & 0.9 \\
\hline Incisive foramina to $\mathbf{M}^{1}$ & 5.6 & 6.5 & 5.7 \\
\hline Length of dentary and $I_{1}$ & 33.0 & 35.2 & 29.2 \\
\hline Length of dentary minus $I_{1}$ & 27.4 & 29.0 & 25.7 \\
\hline Alveolar length of $\mathrm{M}_{1-2}$ & 2.3 & 2.3 & 1.9 \\
\hline
\end{tabular}

emerge from each tail scale, and there are 20 scales per $\mathrm{cm}$ (measured about one-third from the base of the tail). $R$. soricoides has a hairier tail, dark brown all over, and larger scales on the tail $(16$ per $\mathrm{cm})$, probably correlated with its larger size.

The basic conformation of the cranium of $R$. isarogensis is like that of $R$. soricoides - the two are contrasted in Fig. 1. The latter was also illustrated and described by Thomas (1898) and Musser (1969). The primary cranial differences between the two species are in size and proportions, especially width of the cranium relative to its length, rostral proportions, and shape and proportions of the braincase. The cranium of $R$. isarogensis is smaller than that of $R$. soricoides (Table 1 ) and proportioned differently. Breadths of rostrum, interorbital region, zygomatic plate, incisive foramina, palatal bridge, and mesopterygoid fossa are similar in the two species, indicating that the cranium of $R$. isarogensis is wider relative to its length. The rostrum of $R$. isarogensis is absolutely shorter than in $R$. soricoides and shorter relative to length of the cranium (length of rostrum/greatest length of skull is $45 \%$ in FMNH 62289 and $41 \%$ in FMNH 95123). $R$. isarogensis also has a round, more inflated braincase than $R$. soricoides; the braincase is about the same size in the two species, indicating that it is relatively larger in $R$. isarogensis. The mandibles of the two species are similar in shape, those of $R$. isarogensis are smaller and have more robust mandibular condyles. 


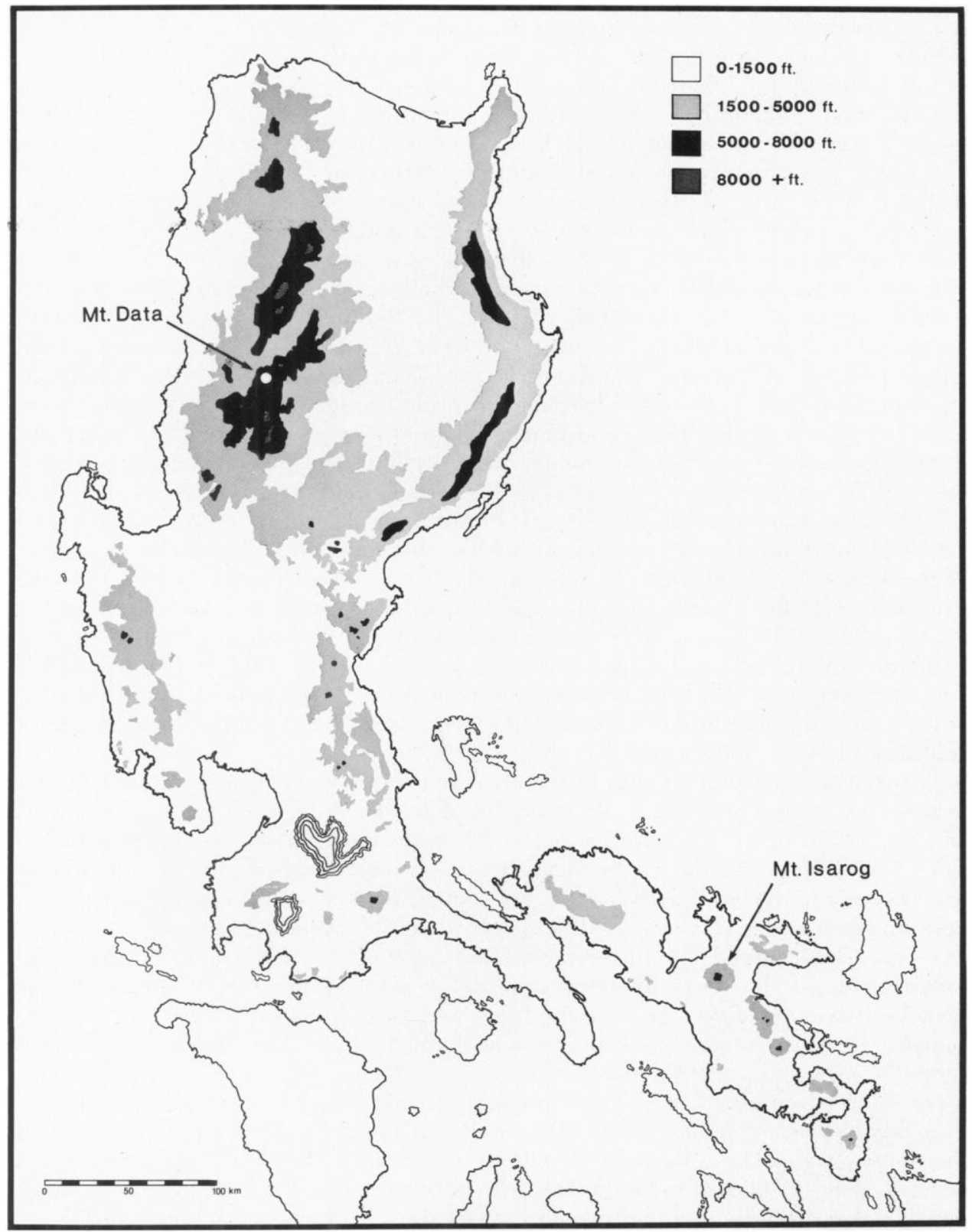

FIG. 2.-The distribution of highlands on the island of Luzon in the Philippines.

The incisors and molars of $R$. isarogensis are white and shaped like those in $R$. soricoides. We found no important dental differences between the two species except possibly a proportional one: the molar row is longer relative to the lengths of palate and cranium in $R$. isarogensis.

Discussion.-Mount Isarog, a volcanic peak that rises to about $6,500 \mathrm{ft}$ above sea level, is located in a region where rains occur year-round, but with a discrete period of maximum rainfall from November to February (Inger, 1954). The upper slopes of 
the mountain are presumbably clothed in montane forest, that according to Inger (1954), gradually merges with lowland forest at about $2,500 \mathrm{ft}$, the actual transitional elevation determined by seasonal rainfall and other factors. Mount Isarog is separated from the highlands of the central cordillera containing Mount Data by extensive lowlands (Fig. 2; also, see King and McKee, 1949). If montane forest occurred at lower elevations and was more widespread during Pleistocene glacial periods, it is likely that the distribution of Rhynchomys was also more extensive than it is now, and possibly even continuous between Mount Data and Mount Isarog. The structural differences between specimens from the two mountains may reflect differentiation after the original population became isolated. Raising of sea level or submergence of parts of Luzon would have also transformed the southeastern Camarines Peninsula into an island, cutting off gene exchange between populations in the mountains there and those in the highlands of northern Luzon. That Camarines was once insular instead of peninsular is indicated by geologic evidence, for Dickerson (1924:41) noted that: "In the low divide between Calauag Bay and Ragay Gulf, an excellent 9-meter terrace marked by coralline limestone, which is found resting uncomfortably upon the truncate edges of Vigo [Miocene] shales, clearly evidences a stage during which a Pleistocene Camarines island existed. Based upon the study of the terrace on the south end of Bondoc Peninsula [the finger-like southeast extension of Luzon just east of the Camarines Peninsula], it is probable that a wide channel existed at a still earlier stage of the Pleistocene connecting the greater Limon Bay with the southern Sibuyan Sea to the south." During late Pleistocene, in Dickerson's (1924:47) reconstruction of the southern Luzon landscape, "... the waters of the Pacific Ocean had a free passage across the northern end of Bondoc Peninsula, and the Camarines island with its smoking sulphurous volcanoes of Mayon, Isarog, and Bulusan, dominated the central Philippine archipelago."

The diagnostic characteristics of the specimen from Mount Isarog are outside the range of variation observed in the examples of $R$. soricoides from Mount Data. This, and the origin of the specimen from an isolated mountain in southeastern Luzon, caused us to recognize the specimen as distinctive, and representative of a population that is reproductively isolated from $R$. soricoides. To recognize isarogensis as a montane subspecies of soricoides would imply incomplete reproductive isolation with the potential to interbreed should the populations ever contact each other. The morphological evidence, however, though drawn from one specimen, supports an hypothesis that the two populations are reproductively isolated; it can be falsified by studying samples of Rhynchomys from intervening highlands, and possibly by results from breeding experiments in the laboratory.

No information about habits or habitat of $R$. isarogensis is available, but the rats probably live in a montane environment similar to that of $R$. soricoides. On the plateau that forms Mount Data, stands of Benguet pine occur on the sides, and mossy forest, consisting mostly of oaks and mountain yew, covers the top above the pine belt (Rabor, 1955). Rabor (1955) noted that two shrew-rats were trapped in thick cover in mossy forest on the perpendicular sides of a deep gully close to the top of the plateau, at about 2,250 m. He stated that shrew-rats were rare in the highland localities; even the Igorot trappers knew nothing of their habits. Additional description of mossy forest in Philippine mountains is provided by Dickerson (1928).

The endemic murids of the Philippines comprise one of the most poorly known groups of rodents in the Far East. Knowledge about their distributions over the archipelago, elevational spread on the mountainous islands, habitats, and biologies is scanty at best. Endemic to Luzon, isolated on mountain tops, restricted to mossy forest, possibly unique in diet, Rhynchomys is one of those murids about which we know very little. The specimen from Mount Isarog adds to the geographic and phyletic 
scope of the genus but contributes nothing to understanding its biology. The murids of the Philippines in general and Luzon in particular need extensive survey and intensive study.

Figure 2 was drawn by $\mathrm{H}$. Sommer and photographed by J. Coxe; the crania were photographed by R. Testa; we appreciate their help. Musser examined specimens at the British Museum (Natural History) through the courtesy of Mr. J. E. Hill. Mrs. F. P. Hufty of Archbold Expeditions Inc. supported Musser's work, both in the field and museum.

\section{Literature Cited}

DiCkERSON, R. E. 1924. Tertiary paleogeography of the Philippines. Philippine J. Sci., 25:11-50.

Dickerson, R. E., ET AL. 1928. Distribution of life in the Philippines. Bur. Sci., Manila, Monogr. 21:1-322.

INGER, R. F. 1954. Systematics and zoogeography of Philippine Amphibia. FieldianaZool., Chicago Mus. Nat. Hist., 33:181-531.

KING, P. B., AND E. M. MCKEE. 1949. Terrain diagrams of the Philippine Islands. Bull. Geol. Soc. Amer., 60:1829-1836.

Musser, G. G. 1969. Results of the Archbold Expeditions. No. 91. A new genus and species of murid rodent from Celebes, with a discussion of its relationships. Amer. Mus. Novitates, 2384:1-41.

. 1970. Species-limits of Rattus brah- $m a$, a murid rodent of northeastern India and northern Burma. Amer. Mus. Novitates, 2406:1-27.

RABOR, D. S. 1955. Notes on mammals and birds of the central northern Luzon highlands, Philippines. Part I: notes on mammals. Silliman J., 2:193-218.

SANBORN, C. C. 1952. Philippine Zoological Expedition 1946-1947. Fieldiana-Zool., Chicago Mus. Nat. Hist., 33:89-158.

Thomas, O. 1895. Preliminary diagnoses of new mammals from Northern Luzon, collected by Mr. John Whitehead. Ann. Mag. Nat. Hist., Ser. 6, 16:160-164.

1898. On the mammals obtained by Mr. John Whitehead during his recent expedition to the Philippines. Trans. Zool. Soc. London, 14:377-412.

Guy G. MusSeR ${ }^{1}$ AND PATricia W. Freeman ${ }^{2}$, ${ }^{A}$ Archbold Expeditions, The American Museum of Natural History, Central Park West at 79th St., New York, NY 10024; 'Field Museum of Natural History, Roosevelt Road at Lake Shore Drive, Chicago, IL 60605. Submitted 25 February 1980. Accepted 14 August 1980.

J. Mamm., 62(1):154-159, 1981

\section{CHROMOSOMAL VARIATION WITHIN FOUR SPECIES OF HARVEST MICE. (REITHRODONTOMYS)}

Chromosomal variation among harvest mice (genus Reithrodontomys) was recently reviewed by Carleton and Myers (1979). Two subgenera (Aporodon and Reithrodontomys) and approximately 19 species are currently recognized (Hooper, 1952; Jones and Genoways, 1970; Jones and Lawlor, 1965) and eight species representing both subgenera have been karyotyped. Considerable chromosomal variation exists (diploid numbers and numbers of autosomal arms range from $2 n=38$ to 52 and $F N=48$ to 80 , respectively); however, intraspecific variation is known only in the number of supernumerary chromosomes present in the karyotype of $R$. megalotis (Blanks and Shellhammer, 1968).

Carleton and Myers (1979) proposed tentative hypotheses concerning evolutionary relationships among harvest mice based on standard karyotypes. Ideally, characters used for species comparisons should be interspecifically variable while remaining intraspecifically stable. Although chromosomal complements of harvest mice meet the first criterion, the degree of intraspecific variation is poorly known. In this paper we document chromosomal variation within four species of harvest mice of the subgenus Reithrodontomys (R. fulvescens, $R$. humulis, $R$. megalotis, and R. sumichrasti) and discuss systematic implications of this variation. 